Izvorni znanstveni rad

DOI: $0.17234 /$ Croatica.41.6

UDK: 003.349.1

821.163.42-97.09

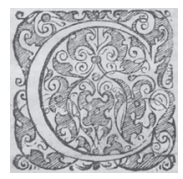

\title{
VARIETAS DELECTAT - NOVI POGLED NA JEDAN HRVATSKOGLAGOLJSKI TEKST
}

\author{
Marija-Ana Dürrigl \\ Staroslavenski institut, Zagreb \\ Znanstveni centar izvrsnosti za hrvatsko glagoljaštvo \\ duerrigl@stin.hr
}

\begin{abstract}
Naslov hrvatskoglagoljskoga prenja s najsloženijom kompozicijom zapravo je doslovan citat iz Biblije: Milost' i Istina sretosta se Pravda i Mir' obcelivasta se (Ps 85,11). To otvara nove mogućnosti razumijevanja teksta-alegorije i njegove višeslojne poruke. Središnji bih postupak nazvala "očudnjenjem" biblijskoga teksta jer slijedi priča s preradbom povijesti ljudskoga roda, od Adamova grijeha, preko Kristove otkupiteljske žrtve, do najave konca vremena kad će svima biti suđeno. Gradba prenja indicira da nije namijenjeno (samo) široj pastvi, nego prije svega krugu onih kojima je bliska lectio divina. U oblikovanju cjeline autor je (pa tako i prevoditelj) posebno nastojao oko postupka/načela varietas: vraćanje na dijelove početnoga prenja četiriju Božjih kćeri (a to su personificirane vrline Milost, Istina, Pravda i Mir), gotovo poput glazbenoga oblika ronda. Pritom se uvijek javljaju makar i neznatne varijacije, novi detalji i stilski postupci. $\mathrm{Na}$ agaru psalamskoga retka izrasli su i alegorija-prepirka Božjih kćeri i prerada spasenjske povijesti svijeta te njezino višeslojno tumačenje/razlaganje, po čemu je djelo jedinstveno među našim prenjima.
\end{abstract}

Ključne riječi: hrvatskoglagoljska književnost, prenja, kompozicija, Biblija, alegorija 


\section{POLAZIŠTE: OD PSALAMSKOGA RETKA DO PRENJA}

"Ja živim u kruzima koji se šire", zapisao je Rilke. Katkad je u znanosti uputno vratiti se na obod područja istraživanja koje se činilo zaokruženim. Kružnica se naime može otvoriti novim pitanjima i može se (naizgled?) zatvoriti novim odgovorom, drukčijom svježom spoznajom.

Hrvatskoglagoljski sastav Milost' i Istina sretosta se Pravda i Mir' obcelivasta se (dalje u tekstu: MI) sačuvan je u tzv. "Akademijinu zborniku" različitoga štiva iz 15. stoljeća (Zagreb, Arhiv HAZU, sign. IV a 48). ${ }^{1}$ Mlađa je verzija krnja, zapisana u rukopisu iz 1773. g. (Zagreb, NSK, sign. R 2375). To je prenje koje po svojim kompozicijskim i misaonim komponentama odskače od ostalih prenja sačuvanih u hrvatskoglagoljskoj srednjovjekovnoj književnosti. Izravni mu predložak još nije točno utvrđen premda Slavomir Sambunjak smatra da mu je autor Bernard iz Clairvauxa te da je jedna njegova propovijed izvor za naš disput. ${ }^{2}$ Upravo način na koji je alegorijski sadržaj oblikovan privlači pažnju svojom specifičnošću.

O (mahom anonimnim) autorima naših srednjovjekovnih tekstova Dunja Fališevac piše: "Srednjovjekovni je pisar, pripadnik kršćanske elite [...] progovorio o sebi s aspekta svoje profesije, svoje staleške pripadnosti društvu molećih", te nadalje, "govoreći o Bogu i Svetim knjigama [...] on je progovorio i o sebi kao čovjeku, o svojem odnosu prema Bogu, o svojim nadama i vjerovanjima." ${ }^{3}$ Specifična nediferenciranost hrvatske srednjovjekovne produkcije ogleda se na raznim razinama, a isto se tako u raznim aspektima toga stvaralaštva mogu uočiti fundamentalne sličnosti i zajednička obilježja. Jedno od takvih jest da je stara hrvatska knjiga, i latinična i glagoljska, "proizašla iz staleža molećih i da je bila pisana prvenstveno za usmeno prenošenje tom istom staležu." "A Ako se promotri sastav knjige u kojoj je MI zapisano, a to je zbornik nabožnoga sadržaja, može se donijeti zaključak o duhovnoj domovini i prvotnoj publici djela - to doista bijaše stalež molećih.

1 Tekst je doživio nekoliko latiničnih izdanja: transkribirao ga je Strohal (1917: 105-113), transliterirao Sambunjak (2000: 257-262), a dio teksta objavljen je u transkripciji u seriji Stoljeća hrvatske književnosti (usp. Dürrigl 2013: 259-266).

2 Usp. Sambunjak 2000: 21-23. Nikola Batušić svrstava tekst među dramske moralitete (usp. Batušić 1978: 12-13, kao i prije njega Strohal 1917: 113).

3 Fališevac 1899: 29.

4 Nav. dj.: 31. 
Dosad se u našoj književnoj znanosti pozornost nije usmjerila na naslov promatranoga teksta, pa se nigdje ne spominje da je to doslovan navod iz Vulgatina prijevoda Psalma 85,11 (odn. 84,11): "misericordia et veritas occurrerunt iustitia et pax deosculatae sunt" ili "Misericordia et veritas

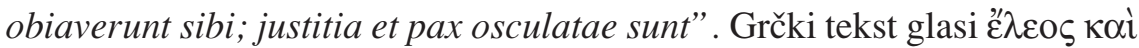

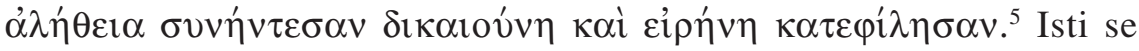
prijevod psalamskoga retka čita i u dvama hrvatskoglagoljskim psaltirima: "M(i)lostb i istina srêtosta se, pravda i mirb oblobizasta se" ${ }^{6}$ Time čitanje/ razumijevanje teksta prenja MI dobiva novu dimenziju.

Tekst MI otvara se naslovom koji je zapravo psalam: Milost' $i$ Istina sretosta se Pravda i Mir' obcelivasta se, a to je nešto što "piše blaženi David v psaltiri v nauk človêčaskago roda". Odmah se nastavljaju citati Sv. Pavla i još jedan psaltirski tekst (Ps 142,6). To je svojevrsna ekspozicija, uvođenje primatelja u sadržaj koji slijedi, a taj se pak apokrifno poziva na Bibliju: "Kako piše v knigah bitiê." Središnji bih kompozicijski, pa i misaoni postupak autora, slijedeći promišljanja Maure Zátonyi, ${ }^{7}$ nazvala očudnjenjem (Textverfremdung) biblijskoga teksta, jer slijedi preradba povijesti ljudskoga roda, od Adamova grijeha preko Kristove otkupiteljske žrtve, do najave konca vremena kad će svima biti suđeno. Pojam očudnjenje rabim kako ne bi došlo do nehotičnoga preklapanja s terminom "očuđavanja" ili "očuđenja", kako ga shvaćaju primjerice Viktor Šklovskij i Bertolt Brecht.

5 Biblia Sacra.www.sbl-site.org/assets/pdfs/bibletexts/Septuaginta/SEPTUAGINTA_SBL.pdf (posjet 10. 06. 2016.) Septuaginta www.sbl-site.org/assets/pdfs/bibletexts/Septuaginta/ SEPTUAGINTA_SBL.pdf (posjet 20.06. 2016.)

6 To su tzv. Lobkowitzov psaltir (iz 1359. g.) i tzv. Pariški psaltir (iz 14. st.), a oba je izdao VAJS 1916. Suvremeni prijevod na hrvatski jezik glasi: "Ljubav će se i Vjernost sastati, Pravda i Mir zagrliti” BIBLIJA 1987: 535 (prijevod Filiberta Gossa). Citati iz glagoljskoga teksta MI donose se prema načelima za izradu Rječnika crkvenoslavenskoga jezika hrvatske redakcije (Staroslavenski institut, Zagreb), s ponešto prilagođenom interpunkcijom i razriješenim kraticama.

7 Usp. Zátonyi 2012, osobito o postupku srednjovjekovnih autora u kojem "muss etwas Vorgegebenes, Vertrautes verfremdet werden, wodurch etwas Fremdes, Neues entsteht [...] in der Rezeption wird dieses Verfremdete durch einen Verstehensprozess angeeignet, was dadurch gelingen kann, dass das Verfremdete auf das Vertraute bezogen wird." - Nav. dj.: 274 ("Nešto otprije znano, otprije poznato treba očuditi, čime nastaje nešto strano, novo [...] u recepciji se to očudnjeno usvaja procesom razumijevanja, što pak proizlazi iz povezanosti očudnjenoga s poznatim" - prev. M.-A. D., s time da izraz Verfremdet prevodim kao “očudnjeno" jer ni u izvorniku autorica ne misli na moderno "očuđenje"). 
Taj je alegorijski motiv, odnosno mesijanska interpretacija psalma, u različitim verzijama i opsezima bio popularan u srednjovjekovnoj latinskoj književnosti, kao i u onima na narodnim jezicima od sredine 12. stoljeća dalje. Korijeni mu sežu dublje u povijest, već u midrašku tradiciju. Djelo je sačuvano i u stihovima i u prozi i u duhovnoj drami, a bilo je uključivano u druga pripovjedna djela (npr. u englesku poemu Piers Plowman iz 14. st., pripisivanu Williamu Langlandu) ili u moralnopoučna djela (mahom propovijedi). Poticaj njegovu širenju dali su, između ostalih, Bernard iz Clairvauxa i Hugo od Sv. Viktora. ${ }^{8}$ Jedna od najpopularnijih verzija jest ona pripisivana Robertu Grossetesteu u djelu Château d' Amour, ${ }^{9}$ a koja ima nekih sličnosti s hrvatskoglagoljskom verzijom. Razvidno je dakle kako je ta tema bila stoljećima omiljena. Činjenica da su i hrvatski glagoljaši u svoj literarni svijet uključili ovaj ostvaraj pokazuje da su bili otvoreni kulturnim utjecajima sa Zapada. Prijepor Božjih kćeri i sinovljeva žrtva bio je podoban vehiculum da se na dramatičan način pokuša protumačiti starozavjetni i novozavjetni pogled na Spasenje/Otkupljenje. ${ }^{10} \mathrm{U}$ brojnim verzijama Istina i Pravda inzistiraju na kazni za neposlušnoga čovjeka, dok Milost i Mir traže oproštenje. Sin je Mudrost Božja koja se utjelovila i tako će spasiti čovječanstvo. ${ }^{11}$

Srednjovjekovna književnost koja je tematiku crpila iz Biblije (tzv. "Bibeldichtung") nije smatrala alegoriju samo hermeneutičkim oblikom ili sredstvom, nego i produktivnim oblikom

[...] etwa in Gestalt der Darstellung des Erlösungsbeschlusses durch den Streit der 'Töchter Gottes' misericordia, veritas, iustitia und pax, für die Bernhard von Clairvaux die Anregung gegeben hat. Eher noch aber denkt man bei den Versen

8 Usp. Achnitz (ur.) 2011: 1028. Motiv je bio opjevan i u njemačkom Meister(ge)sangu.

9 Usp. Newman 2001: 194-195, osobito o odnosu gospodara i kćeri, te o razrješenju "sukoba" u smislu anselmovske teologije iskupljenja.

10 Usp. Owst 1933: 90-93. Autor oprimjeruje i mogućnost obrade toga motiva u propovijedima. O ponešto problematičnom odnosu Boga, njegova Sina i "boginja” kao što su npr. alegorijske Božje kćeri (koje se kadšto poistovjećuju s vrlinama) usp. Newman 2001.

11 Nav. dj., str. 216. U obradbi Huga od Sv. Viktora spas donose samo pokora i pokajanje. Neki teolozi zreloga srednjovjekovlja držali su da se upravo "suradnja" milosti i istine može prepoznati u čovjeku i njegovu djelovanju u ukupnosti povijesti čovječanstva. Osim toga Sv. Hildegarda iz Bingena u djelu Scivias piše da je "Filius [...] speculum in virtutibus" - dakle Krist se ljudima reflektira kroz vrline, pa tako i one o kojima je riječ u ovom alegorijskom prenju. $S$ druge strane vrline su ratnici (ratnice?) koje se bore za Boga i koje će pokajnike dovesti do rajske radosti. 
des Nicole Bazon an das Gedicht des Euphemius aus dem 12. Jahrhundert, ohne dass freilich ein unmittelbarer Zusammenhang zwischen beiden Texten hergestellt werden kann. ${ }^{12}$

I tu je pitanje izvornoga autorstva ostavljeno otvorenim.

\section{ALEGORIJA, OČUĐENJE I VARIJACIJA}

Nevelik sačuvani korpus hrvatskoglagoljskih proznih prenja odlikuje se time što svako pojedino prenje ima ne samo sadržajne nego i stilističke posebnosti. Kompozicija i stil prenja MI indicira da ono nije namijenjeno (samo) široj pastvi, nego prije svega krugu onih kojima je bliska lectio divina, a da se autor zalagao za postupak ili načelo varietas. Držim da to ipak nije nešto što se približava "dojmu pučke maštovitosti i istrajnosti u njoj, u dojmu o naivnosti koji proistječe iz glagoljaševe ljubavi prema 'ežemplu' i prema fabuli."13 Varietas iz naslova ovoga rada ne odnosi se samo na to da je u MI varirana jedna često ponavljana tema, već da je tekst kao cjelina "sa-stavljen" (!) od dijelova koji se s više ili manje razlika variraju i ponavljaju. ${ }^{14}$ Stalno vraćanje na isto nije (samo) odraz predilekcije za fabuliranje, već postupak koji učvršćuje pamćenje, istovremeno pozivajući na novo prihvaćanje pouke koja se daje kroz očuđenje biblijske priče. No te varijacije nisu nasumične, one su važne za "vođenje" primatelja kroz djelo, ${ }^{15}$ ali i za to da opetovanu, već poznatu priču, zaodjenu u drukčiji oblik i tako ne pruže (sit venia verbo) samo užitak, nego i da izlože nove mogućnosti razumijevanja teksta i njegove višeslojne poruke. Varijacije uvijek iznova bude pozornost i znatiželju,

12 Kartschoke 1984: 33. U prijevodu: “[...] otprilike u obliku prikaza završnoga otkupljenja kroz prijepor 'Božjih kćeri' milosti, istine, pravde i mira, za što je poticaj dao Bernard iz Clairvauxa. No u stihovima Nicole Bazona prije pomišljamo na Eufemijeve stihove iz 12. st., ali se izravna veza među dvama tekstovima ne može ustanoviti." Zanimljivo je primijetiti kako se u europskim vernakularnim književnostima samostalne alegorije pojavljuju kasnije nego u književnosti na latinskom jeziku.

13 Sambunjak 2000: 22.

14 Detaljno o postupku i fenomenu varietas usp. Carruthers 2009, u ovom razmatranju pojam je shvaćen ipak uže.

15 "Variety is essential to ductus; indeed the variety of a work constitutes its ductus"-Carruthers 2013: 137 ("Varijacija/raznolikost temeljna je za ductus; zaista, raznolikost djela tvori njegov ductus") i nadalje: "[...] without enough varietas, an audience becomes satiated and bored"nav. dj.: 138-139 ("[...] bez dovoljno varietas publika postaje zasićena i dosađuje se"). 
otvaraju mogućnost iščitavanja/prepoznavanja novih, drukčijih detalja unutar zadanoga okvira. Prvotna je ciljana publika (redovnici) mogla tekst lako prepoznati jer je MI izraslo iz psalma koji se redovito kazivao/pjevao. Način interpretacije biblijskih sadržaja neizostavno uključuje pamćenje, a s druge strane potiče niz asocijacija - ovo potonje sa suvremenoga stajališta nazvali bismo kreativnošću. Tako poznati biblijski sadržaj biva "preoblikovan" u novu građevinu ${ }^{16} \mathrm{u}$ novu strukturu - upravo u prenje i sermon MI. To je još jedan primjer kako neki poznati tekst biblijskoga čitanja postaje ishodištem za inventio i constructio, a u konačnici i za moralnu pouku. ${ }^{17}$

Promatrani je tekst očito alegorija. Srednjovjekovnu je alegoriju teško, dapače, nemoguće definirati s gledišta onodobne "književne teorije", jer nisu sačuvane upute za pisanje alegorija. Postoje tek rječnici alegorijskih pojmova i odnosa, kao primjeri za sastavljanje takvih djela. ${ }^{18}$ Dakako, temelj za srednjovjekovne alegorije je dvostruk: s jedne strane jednostavno pisanje aliud verbis, aliud sensu na tragu Kvintilijana, a s druge je strane interpretacija Svetoga pisma i njegove četiri (katkad tri) razine značenja. Trostruko ili četvrostruko značenje Sv. pisma isticali su već Origen (2-3. st.) i Kasijan (4-5. st.), a možda je najpoznatija misao Jeana Gersona (14-15. st.): "Littera gesta docet/quid credas allegoria/moralis quod agas/quo tendas anagogia". Dakle, alegorijsko tumačenje trebalo je biti smjerokaz za vjerovanje. Budući da je kod MI riječ o obradbi biblijskoga teksta, nije vjerojatno da se mnogoslojnost tekstovnoga značenja dovodila u pitanje. ${ }^{19} \mathrm{U}$ srednjem je vijeku Sveto pismo bilo polazište i temelj za hermeneutiku koja se odnosila na "interpretacijsko" poimanje života i svijeta - ovozemna je stvarnost sagledavana kao nositelj ili zrcalo dubljega, vječnog značenja. Takvu ulogu ima i psalamski redak u MI: kroz prijepor, rudimentarnu priču i egzegezu (moralnu pouku) pomoći primateljima da svrsishodnije i bolje žive. Dakako, djelo potječe iz onoga duhovnoga/duhovničkoga okruženja koje ne nastoji

16 O tropu građenja i umjetničkih djela kao građevina usp. npr. Carruthers 1993.

17 O tim fenomenima usp. utjecajne rasprave Carruthers 1990. i 1998.

18 Usp. Glier 1984: 203-206.

19 Teološki nazori o alegorijskom čitanju Biblije veoma su raznorodni tijekom dugoga razdoblja što ga zovemo srednjim vijekom; već je Sv. Augustin bio svjestan snage alegorije u čitanju i razumijevanju Sv. pisma, ali je upozoravao i na opasnost "zamagljivanja" doslovnoga značenja tekstova, usp. Maconi, Stump 2014: 3 i 311 . O alegorijskom tumačenju Sv. pisma usp. i Zátonyi 2012: 56-62, s opsežnom literaturom. O alegoriji općenito u srednjem vijeku usp. Minnis 2000: 231-256 te sažeto i pregledno u Grmača 2015: 41-62. 
oduzeti živost biblijskoj slikovitosti i "prevesti" je u pojmove. Naprotiv, to ozračje stvara novu, vlastitu slikovitost.

U svojoj cjelini hrvatskoglagoljski je tekst MI mješavina žanrova. U njemu se prepoznaju: I. biblijski citat (koji funkcionira i kao "naslov"); II. prenje (s elementima psihomahije), legendarno-apokrifni dio; III. egzegetski dio, tj. tumačenje ispripovijedanoga kroz alegorezu (najopsežniji dio djela); i naposljetku IV. zaključak, sukus oblikovan gotovo kao sermon, propovijed (s još jednim "malim prenjem" Milosti i Pravde, koje je parafraza ideje iz Pavlove poslanice Titu 3,5, odnosno detalja iz propovijedi Sv. Bernarda u kojoj stoji o Kristu na nebesima: "habens in dextera misericordiam, in sinistra iudicium" ${ }^{20}$ ). Konac teksta označen je riječima Milosti, opet citatom iz psalama i s molitvenim zaključkom koji se, tipično, širi na sve članove komunikacijskoga procesa: "Pomozi nam Bože spasitelû naš' i ciĉ' velike slave imene tvoego svetago spasi nas' va vêki amen'."

Upravo činjenica da u organsku cjelinu teksta ulazi i tumačenje ispripovijedanoga/izloženoga individualna je značajka ovoga teksta, što ga jasno izdvaja od ostalih sačuvanih hrvatskoglagoljskih prenja. Po svojoj je dakle kompoziciji MI kao cjelina - u manjoj mjeri njezini dijelovi, ako se uopće smiju međusobno dijeliti - jedinstven ostvaraj naše srednjovjekovne književnosti. To se prenje izdvaja i po tome što autor kombinira pripovijedanje u trećem licu s dijalozima i (kraćim) monolozima te što spaja moduse pripovijedanja i tumačenja s izravnim upozorenjima primateljima. Dakle i te su varijacije dio specifične kompleksnosti građe MI u odnosu na druga glagoljska prenja; one se zapravo odnose na "dodavanje" različitih razina tumačenja i upozorenja, ali uvijek kroz (makar skučeno) fabuliranje i dijalog.

Zanimljivo je da dio koji nazivam egzegetskim (a koji se nastavlja na prenje) sadrži kraće cjeline koje sam nazvala malim prenjima, a koja su važna i za egzegetski dio, ali i za ukupnost ostvaraja. Taj se dio teksta otvara brojnim citatima ili parafrazama iz Staroga zavjeta i iz Evanđelja; priča o gospodaru i sluzi tumači se tako da se ponavlja cijela biblijska priča o Adamovu padu, o četirima mučiteljima koji od tada vrebaju čovjeka (telu svetu d'êvlu črvom'). Česti su i citati iz djela teoloških autoriteta, osobito Sv. Augustina i Sv. Bernarda. Prenje sestara tumači se Biblijom, a Biblija cita-

20 Cit. prema Schulze 1980: 165. Nadalje se kaže "in dextera aquam, in sinistra ignem immobiliter tenens.” To je dakle ono što slijedi čovjeku - očišćenje vodom spasa ili pak vatra vječne kazne. 
tima iz djela crkvenih otaca. Zatim se iznova prepiru sestre Pravda i Milost, s time da autor u usta Milosti stavlja biblijski tekst "pakal' ne ispovêdaet' se tebê ni semrt' pohvalit' te" (Iz 38,18). Nastavlja se tekst o Isusovu utjelovljenju i muci, a na tom ga putu prati njegova sestra (!) Milost; Pravda i Istina uklonile su se. Završni odsječak teksta počinje propovjednim, ali i afektivnim izravnim obraćanjem primatelju: "O človêče grêšni pomisli doklê hoĉe biti gospodstvo tvoe i vlast' Milosti kada nam' tako grozno Pravda prêti!"

Može se poći korak dalje i kazati kako su dijelovi što pripadaju različitim diskursima (pripovjednomu, možda dramskomu i egzegetskomu) u ovom sastavu toliko međusobno povezani - jedan iz drugoga izvire i ponovno se u njega vraća - da ih nije moguće jasno i strogo odijeliti bez bitnoga narušavanja jedinstva i ravnoteže djela. Uvjetno sam, posudivši terminologiju starije farmacije, utvrdila da na površinskoj razini legendarno-apokrifni uvod, prenje i (alegorijsko) tumačenje tvore compositum žanrova, a na dubljoj se razini razaznaje svojevrsni mixtum-postupak (pretapanje žanrova i modusa). ${ }^{21} \mathrm{U}$ ovom je razmatranju međutim naglasak na postupku očudnjenja i na stalnom, opetovanom odijevanju ishodišne (pa i zaključne!) misli u nove i nove rečenice, odlomke, mala prenja, tj. na postupku varijacije. Uopće se kod čitanja MI stječe dojam - varietas delectat. Činjenica da izravan književni predložak za MI još nije eruiran otežava donošenje zaključaka - ne znamo naime smijemo li govoriti o umješnosti i kreativnosti glagoljaša da tako sastavi djelo, doslovce da ga "sa-stavi", ili je složenu kompoziciju preuzeo iz predloška? Na svaki je način ipak moguće iz teksta opet iščitati postupke dekompozicije, rekolekcije i spajanja lajtmotivski vezanih odsječaka. Tako se može ustvrditi da je u ovom tekstu lakše prepoznati "put" (ductus) kojim se primatelj vodi kroz razgovor i priču nego je slučaj u drugim našim prenjima.

U tradiciji sličnih alegorijskih djela koja se odnose na eshatološku sferu nazire se daleka sličnost i s Liber divinorum operum Sv. Hildegarde iz Bingena, kao is njezinim Liber vitae meritorum: ${ }^{22}$ vraćam se na fenomen

21 Usp. Dürrigl 2003 i 2007. Tamo su obrađene i najznačajnije retoričkofiguralne značajke teksta.

22 Potonje je djelo viđenje/slušanje prenja među grijesima/prijestupima i vrlinama. Ova je paralela možda i daleka, jer se kod Hildegarde radi o duboko teološkim djelima s bujnom, vrlo individualnom slikovitošću; no namjera mi je pokazati kako MI najvjerojatnije potječe iz sličnoga redovničkog duhovno-estetskoga miljea. Pritom valja ipak naglasiti kako Liber vitae meritorum nije djelo namijenjeno široj publici, već za čitanje u samostanskom refektoriju. 
ili postupak očudnjenja teksta - u našem slučaju, dakle u tekstu MI, jednoga psalamskoga retka. U Hildegarde prvo dolazi slikovita, dojmljiva (narativna) vizija ili dramatično prenje/disput. Zatim se prelazi u didaktičan i alegoričan modus s citatima iz Biblije i crkvenih autoriteta gdje se razrađuju dijelovi iz vizije/prenja, ali se i u tom drugom dijelu kao govornici pojavljuju dramatis personae iz prvoga dijela. U završnici se neke podrobnosti ponavljaju i stavljaju u novi kontekst i daju im se duža tumačenja, gotovo kao tekstovi biblijskih komentara. Možda se, s dalekom paralelom prema spomenutim djelima, i kompozicija našega teksta MI može gledati prema trima fazama intelektualne aktivnosti: čitanje (pamćenje) - meditacija - kontemplacija (koja uključuje disciplina i virtutes). ${ }^{23} \mathrm{Ili}$, drukčije kazano, zadržavanje u pamćenju, "ponovno slaganje" dijelova/odsječaka u nove cjeline i interpretacija te cjeline.

U MI ishodišno prenje Božjih kćeri djeluje kao teglenica za sve pouke i poruke koje se žele prenijeti, bilo kroz naraciju, bilo kroz izravno tumačenje. Predložila bih pogled koji dopušta tvrdnju da je riječ o teologiji odjevenoj u prenje, a sve je prožeto benediktinskom tradicijom lectio meditatio oratio. Naime čitanje (pa i slušanje) uključuje cijeloga čovjeka, njegov razum, osjećanje i ponašanje. ${ }^{24}$ Kroz sadržaj koji si primatelj može predočiti (personifikacije, slike, zaplet i rasplet, rasprava/svađa itd.) on pokušava doprijeti do netvarnoga, do vječne Istine; "skrivanje" pak poznatoga kroz očuđenje u njemu izaziva pozornost pa i kreativnost u prepoznavanju analogije, poveznice i pouke.

MI je jedino naše prenje za koje se može kazati da je alegorija, premda neki znanstvenici drže da je svaka personifikacija zapravo alegorija - u tom bi slučaju i druga naša prenja bila alegorična. ${ }^{25}$ No ovdje je autor svjesno i oblikom i sadržajem i izrijekom učinio jasnim da mora dati tumačenje onoga o čemu se pripovijeda, o čemu se i tko se spori, dakle daje alegorezu ili "egzegezu" prvoga dijela teksta. A srž toga prenja temeljna je biblijska priča o ljudskoj povijesti, temeljena na Ps $84,11(85,11)$. Čovjek je officiale opus, kazala bi Sv. Hildegarda, stvorenje s određenom zadaćom sudjelovanja u spasenju - stoga je temeljna poruka djela MI, njezin Sitz im Leben (da upotrijebim taj termin, pa makar bio neprikladan) na dramatičan način

\footnotetext{
23 Tako ih definira Hugo od Sv. Viktora, usp. iscrpnu analizu u Coolman 2010.

24 U idealnom slučaju čitanje povezuje sam fizički čin čitanja (ili slušanja), vjeru, uvid i razumijevanje (intellectus), usp. Zátonyi 2012: 94 i Carruthers 1998.

25 Jer se u njima kao likovi pojavljuju smrt, duša, tijelo, ili misao/mišljenje.
} 
oživjeti biblijsku poruku, očudnjujući je kroz prenja i alegoriju/alegorezu. Očudnjenje je u temelju teksta MI, pa se može postaviti pomalo smjela tvrdnja da on potječe iz zapadnoeuropske redovničke tradicije gdje takav postupak nije neobičan. ${ }^{26}$

\section{KOMPOZICIJSKI RONDO I MEMENTO}

Ostvaraj MI dakle ima trostruku, dapače, četverostruku građu. Naime ako se formulacija “Milost' i Istina sretosta se, Pravda i Mir' obcelivasta se" ne gleda kao nešto paratekstualno (kao naslov odvojen od teksta), tada je ona "prva" razina teksta, ono doslovno ishodište na koje se nadograđuju sljedeći odsječci. Prvi je dio narativnodijaloškoga značaja priča o gospodaru, njegovu neposlušnom sluzi, o prenju četiriju gospodarevih kćeri i konačnoj sinovoj žrtvi. Drugi je dio alegoreza; njime se tumači ono što je u prvom dijelu ispričano, a ponavljanja čitavih konstrukcija iz prvoga dijela nisu stilska nedosljednost, već namjera da se ostvari dublje razumijevanje i usvajanje sadržaja. ${ }^{27}$ To je, ipak, i novo čitanje, dok treći dio djela funkcionira kao sermon, kao poziv primateljima da čuveno usvoje i da po tome žive. Zanimljivo je da u rukopisu HAZU IV a 48 prvi dio teksta počinje ukrašenim inicijalom "M" ("Milost i Istina...", početak naslova teksta), a drugi dio također ukrašenim inicijalom "S" ("Sada more se iskati..."), dok treći dio nema posebnoga vizualnog indikatora početka. Na stil MI može se primijeniti izraz Beverly M. Kienzle, da je naime riječ o "dramatic narrative", o povezanosti dramskoga/dramatskoga s narativnim. ${ }^{28}$ Opet se valja vratiti na emotivnost, na važnost osjećaja.

To je osobito vidljivo u III. dijelu kada sveznajući pripovjedač (autor?) роис̌ava recipijente: "Hoĉeš li izviditi da e miran' ere on' vazda v miru

$26 \mathrm{Tj}$. postupak očudnjenja s (višestrukim) tumačenjima, npr. u djelima sv. Hildegarde iz Bingena, Ruperta iz Deutza ili Huga od Sv. Viktora. Pred našim je tekstolozima i književnim povjesničarima zadatak pronalaženja izvornika za hrvatskoglagoljsku verziju MI.

27 Nameće se paralela s Hildegardinim Liber divinorum operum. Tamo u 10. viziji Pravda vapi i upozorava na Božji gnjev koji će se izliti na čovječanstvo; no Bog ponavlja da strpljivo čeka na obraćenje grešnika. Pravda će pak "procvasti” (tj. uzrast će njezina viriditas, zelena snaga životnosti i obnove) u dolazećem vremenu Mira, što je opet svojevrsno očudnjenje, tj. obrada teksta iz knjige proroka Izaije, usp. Hildegard von Bingen 1998: 426-440.

28 Kienzle 2000: 149. Ona tu sintagmu rabi za homilije Sv. Hildegarde iz Bingena, koje u svojoj egzegetskoj cjelini uvijek spajaju poučno, pripovjedno i dramatsko. 
prebiva i mir' ljubi i on' po milosti svoei mir dae svoim' učenikom' kako piše sveti Ivan' Mir' ostavlaju vam' i mir moi daju vam"”; plaši ih: "stanovito znamo da umrêti imamo da ne znamo kada i kako i kadi A va vsako vrime nas' semrt' čeka i vaz'di e pripravna k nam"'; potiče ih: "o pogledai človêče svoga tela velike tamnosti i gnusa"; "da ako bismo mudri bili mi bismo e pripravni čekali”, autor/pripovjedač/propovjednik obećava nadu u spas sve to kroz niz citata iz Biblije i crkvenih autoriteta, ali ne mogući se othrvati upravo nagonu da svako malo "ubaci" pokoji mikrodijalog ili pokoje izravno obraćanje primatelju, pa se "ponovo" pojavljuje malo prenje, ali uvijek s varijacijom, s nekom novinom kao prisjećanje na već izgovorenu svađu Božjih kćeri, s namjerom pojačavanja dojma, produbljivanja značenja i objašnjenje pouke.

Naši su srednjovjekovni tekstovi izrazito retorični u smislu da uvijek netko govori - valjalo je publiku vjerskih tekstova poučiti i uvjeriti. Na to se odnose i antička i srednjovjekovna retorika. Actio/pronuntiatio je govor kojim se slušatelj pridobiva, "osvaja", ${ }^{29}$ povjerenje se ne postiže samo dogmom ili "dokazima" (čudesima, egzemplima itd.), nego se nastoji slušatelja "zagrijati" (incalescere) za poruku i sadržaj kroz osjećaje koji se u njega pobuđuju, kako je upravo pokazano. ${ }^{30}$

Tišine u djelu gotovo da i nema jer se stalno uvode novi govornici. ${ }^{31}$ Osjeća se horror vacui, pa u tekstu nema praznoga hoda. Ni sestre se zapravo

29 Usp. Carruthers 2013: 38.

30 Osim toga nije naodmet ponoviti da "it is certain that many of the poems were written to specific audiences, addressing concrete historical circumstances, with a view of securing a response from those readers, a response which went beyond enjoyment to conviction and action." (Prill 1987: 147) ("nesumnjivo su mnoge od pjesama napisane za određenu publiku i odnose se na konkretne povijesne okolnosti, s ciljem da izazovu odgovor tih čitatelja, odgovor koji je išao i onkraj užitka, prema uvjerenju i djelovanju"). To se može primijeniti i na našu nabožnu prozu (koja možda i nije bila samo "čitana za sebe"), tj. da je uopće vjerska (dakle, "angažirana") srednjovjekovna književnost bila izrazito retorička.

31 Slušanja međutim ima u Liber vitae meritorum gdje se za riječ također javljaju personificirane vrline. Milost u Liber vitae meritorum tvrdi da je ona bila dijelom božanskoga fiat! po kojemu je sve počelo, ona je ukrašena stanovnica Božjega dvora i njegova savjetnica; Pravda kaže kako je Božja prijateljica koja djeluje jednako u grmljavini kao i u blagosti janjeta; Pravda nikad neće nestati, ona je u pobjedi Gospodnjoj; Milost je sastavni dio viriditas, životne sile ili snage koja prožima sve. Istina nadalje inzistira na tome da čovjekova zla djela uništavaju tu viriditas svijeta što ga je Bog stvorio; ona pak sebe naziva Božjom trubljom pravednosti. Mir naglašava važnost slušanja dobrih savjeta i sebe uspoređuje s prostorijom (u našem se tekstu spominje kamara u koju sluga ne smije ući!) u koju svi trebaju težiti ući. Mir je lijek i ljekoviti balzam, on je miomiris oprosta, usp. Hildegard von Bingen 2014. 
"međusobno ne slušaju" u smislu neke razmjene ideja; svaka želi pridobiti oca da učini baš ono što ona zahtijeva. Slušanje, razmišljanje, promišljanje ostavljeno je primatelju, a ne likovima - čak kao da nije ostavljeno ni pripovjedaču.

Ono što se zamjećuje jasnije nego u drugim glagoljskim disputima jest česta promjena pozicije (glasa, gledišta) govornika: sveznajući pripovjedač - likovi u prenju/u sukobu - autorski pripovjedač (glasom, manirom propovjednika) - autoriteti koji se citiraju/parafraziraju ${ }^{32}$ - "novi" likovi (npr. đavao/zmija) - već poznati likovi iz početnoga prenja (kćeri, otac, $\sin$ ) - autorski pripovjedač. U prenju se i sam Bog javlja kao lik na način da gospodar razgovara sa sinom i njega pita za savjet (!), a pripovjedač-sveznalica izrijekom kaže da je sin zapravo Krist, iz čega proizlazi da je gospodar Bog: 'i dozva toga svoga premudroga sina svoga na svet' to est' gospodina našega Isuhrbsta i reče $\mathrm{k}$ nemu: $\mathrm{O}$ sinu moi dragi slišišs ta vapai i karbu meju pravdu i milostiju? Ča ti e viditi e li vrime jure pomilovati človêka? A sin' milostivi reče: Otče moi dragi ostavi na me ta dlg' i to brime."

U porabi epiteta (predragi, milostivi) osjeća se "glas vodič" sveznajućega pripovjedača čijim se riječima vjeruje. ${ }^{33} \mathrm{Na}$ kraju teksta, u dijelu koji se može gledati kao sermon, sveznajući se i autorski pripovjedač stapaju, ne može ih se razlikovati, a to je razumljivo jer nije riječ o strogo narativnom tekstu. Ključna je dakle značajka već spomenuto očudnjenje jer autor miješa alegoriju (prenje) s tumačenjima i izlaganjima koja opet uključuju prenja i razgovor: stalno pozivanje primatelja na novo i novo slušanje (u pretpostavljenoj izravnoj prelekciji) ili pak na ponovno čitanje fundamentalno istih pouka, ali "odjevenih" u novi oblik. To je na tragu srednjovjekovne poetike te načina na koji su doživljavana i shvaćana književna djela: autori nisu težili spontanim, individualnim kreacijama, nego su kroz preuzete, tradicionalne slike oblikovali, dapače preoblikovali naslijeđene ideje u "svojim" ostvarajima - upravo, varirali su ih. ${ }^{34} \mathrm{U}$ sastavu MI stalno se osjeća

32 Navode se Sv. Bernard: "o pogledai človêče svoga tela velike tamnosti i gnusa", evanđelist Luka: "budite milostivi kako i otbc' vaš‘ nebeski milostiv' est'”, Sveti Augustin: "O svete nečistivi i nevêrni kolika est' na tebê muka i trud' človêku" i dr.

33 Namjera se uvijek nalazi unutar nabožnoga djela, ona se ne odnosi na (novovjeko) usmjeravanje na osobu autora-umjetnika: "Intentio auctoris - in this sense - is a useful concept for studying medieval arts." (Carruthers 2013: 53) ("Intentio auctoris - u ovom smislu - koristan je koncept za proučavanje srednjovjekovne umjetnosti.")

34 "Even the authors whom we consider the most modern, Villon or Rabelais, for example, were reshaping traditional materials" (Arden 1987: 21) (“Čak i autori koje smatramo najmodernijima, primjerice Villon ili Rabelais, preoblikovali su tradicionalne izvore.”) 
napetost, ali i povezanost između vjerskoga sadržaja/teme koja se temelji na Bibliji ("alegorije", slikâ) i tumačenja, diskurzivnoga objašnjenja i izlaganja. Pritom (jer je riječ o nabožnu i pobudbenu djelu) valja reći da vjera nije samo usvajanje i prihvaćanje određenoga sadržaja, nego i povjerenje (fides). Naglasak je dakle na tome što likovi osjećaju (sestre se ljute, viču, prijete ili mole, čak kao da ucjenjuju oca - "i ako pravadan' ne budeš' mene Istinu ne budeš' imêti za h'cerer"; sin je pun razumijevanja i krotak; gospodar je razočaran i tužan, čak ogorčen - "kaû se da sam' učinil človêka") ${ }^{35}$, pa preko njih i na tome što slušatelj osjeća, od straha do radosti.

Isto tako, s gledišta performativnosti, prepoznaje se napetost između modusa kazivanja i prikazivanja, kao stilistička vrijednost naših srednjovjekovnih tekstova. To dvojstvo u kompoziciji - koja ovim načinom gledanja gubi negativne epitete koje su stariji istraživači ponekada na ta djela primjenjivali omogućuje glagoljašima (makar i bili samo prevoditelji) da ostvare puninu umjetnosti riječi, da iskoriste jezičnostilske mogućnosti u oblikovanju fabule, likova i poruke. Ono što katkad govoreći o hrvatskoglagoljskim tekstovima nazivamo sermo humilis, ne smije se smatrati niskim stilom kao posljedicom neukosti ili folklornih utjecaja. Naprotiv, ovo djelo izvorno nije bilo namijenjeno neukima - ni latinska ni hrvatskoglagoljska inačica. Činjenica jest da srednjovjekovni autori (za razliku od antičkih) pišu za pripadnike različitih društvenih (pa tako i "obrazovnih") slojeva, te se moraju publici prilagođavati, koristiti razne stilove i diskurse da budu pristupačni i razumljivi. MI po jezičnostilskim značajkama nije izdvojeno u odnosu na druga prenja (ili u odnosu na ukupnost hrvatske srednjovjekovne pripovjedne proze) jer su mu stilske odlike slične onima u drugim sačuvanim hrvatskoglagoljskim prenjima. Sukob koji se ostvaruje/događa na više razina, stalno izmjenjivanje paralelizama s antitezama, doprinosi živosti i dojmljivosti djela. Ponavljanje pak i vraćanje na dijelove ishodišnoga prenja Božjih kćeri, gotovo poput glazbenoga oblika ronda ili teme s varijacijama (premda analogije s drugim umjetnostima nisu adekvatne), također je vrsta ruminatio, stalno vraćanje u svijest primatelja (i u njihova srca) onoga o čemu se na početku govorilo, tj. onoga što je hrana za spasenje. Zanimljivo, najčešće je takvo vraćanje odjenuto u poziv na strah, pokoru, skromnost i

35 I kad ne navodi izvor, autor rabi biblijske citate, kao što je ovaj iz Post 6,7. Uopée bi bilo zanimljivo tražiti biblijske citate u zborničkim tekstovima kako bi se i njima upotpunio korpus sačuvanih biblijskih čitanja i odlomaka u hrvatskoglagoljskoj tradiciji. 
poslušnost. ${ }^{36} \mathrm{U}$ tom vraćanju i očudnjenju s varijacijama smijemo prepoznati odjeke samostanske lektire.

\section{UMJESTO ZAKLJUČKA}

Prvi je dio teksta MI afektivan dok su drugi i treći dio smireniji. Specifična propovjednost teksta MI jasno dolazi do izražaja; ono pak o čemu se pripovijeda ima značaj ukazivanja. Još je jedan detalj važan: u prenju četiriju Božjih kćeri, grešni sluga (čovječanstvo, ali i svaki čovjek napose) ima tek pasivnu ulogu - on je zgriješio i pao u napast, ali ga izbaviti može samo Bog neizmjernim čudom svoga otjelovljenja u Sinu. Međutim u zaključnom "sermonskom" dijelu teksta upravo se svaki čovjek poziva na aktivnu, svjesnu ulogu u vlastitu iskupljenju i spasenju.

MI je jedan od vrhunaca hrvatskoglagoljskoga pisanog nasljeđa i dokaz kako smo bili dionici (premda možda s vremenskim odmakom) jedne zajedničke književne i duhovne tradicije. Naši su prevoditelji i takva djela umjeli prenijeti u manje učenu glagoljašku sredinu koja ipak u srednjem vijeku nije nikakav zabran, već dio europske kulturne i književne tradicije. Riječ je o složenoj tekstnoj strukturi koja se, doduše, može razložiti na tri veća dijela, ali ponavljanja i spiralno kretanje kroz cjelinu ipak omogućuju dublji pogled i jasniju poruku publici. U tome se očituje postupak ali i načelo varietas ono izlaganje pouke čini dramatičnim držeći istovremeno primatelje u stanju znatiželje i pozornosti. "Približavanje kroz očudnjenje" biblijskoga teksta (i priče o Adamovu prijestupu i Kristove muke po kojoj je čovjek otkupljen) postupak je koji u sebi uključuje kreativnost i maštovitost, pa po tome držim da je MI iznimno među našim prenjima. Posebnost je, dakako, i to što u cjelinu teksta ulazi višeslojno tumačenje ishodišnoga prenja među personificiranim likovima.

Da zaključim: na agaru psalamskoga retka Milost' i Istina sretosta se Pravda i Mir' obcelivasta se izrasli su i alegorija-prepirka Božjih kćeri i njezino višeslojno tumačenje/razlaganje (povezano s biblijskom pričom spasenja, od praroditeljskoga grijeha do Kristova otkupljenja), po čemu je djelo jedinstveno među našim prenjima. Prema dosadašnjim istraživanjima

36 Gotovo kao u suvremenu psihoanalitičkom poimanju ruminacije kao stalnoga prisjećanja na neugodne doživljaje, uz osjećaj krivnje i kajanja. 
MI je jedini naš zbornički tekst čiji je naslov doslovni navod biblijskoga teksta. Osim toga tekst je dokaz kako su glagoljaši u svoju sredinu i tradiciju unosili popularna djela europskoga srednjovjekovlja, što i danas otkrivamo kao dokaz o ars verborum hrvatskih prevoditelja-pisaca i kompilatora.

\section{LITERATURA}

Achnitz, Wolfgang (ur.). 2011. Deutsches Literatur-Lexikon: das Mittelalter, Bd. 1, Walter de Gruyter, Berlin New York.

Arden, Heather. M. 1987. The Romance of the Rose, Twayne Publishers, Boston.

Batušić, Nikola. 1978. Povijest hrvatskoga kazališta, Matica hrvatska, Zagreb.

Carruthers, Mary. 2013. The Experience of Beauty in the Middle Ages, Oxford University Press, Oxford.

Carruthers, Mary. 2009. "Varietas": A Word of Many Colours, "Poetics" 41, str. 11-32.

Carruthers, Mary. 1998. The Craft of Thought. Meditation, Rhetoric and the Making of Images, 400-1200, Cambridge University Press, Cambridge.

Carruthers, Mary. 1993. The Poet as Master Builder: Compositional and Locational Memory in the Middle Ages, "New Literary History" 24, str. 881-904.

Carruthers, Mary. 1990. The Book of Memory. A Study of Memory in Medieval Culture, Cambridge University Press, Cambridge.

Coolman, Boyd. T. 2010. The Theology of Hugh of St. Victor, Cambridge University Press, Cambridge.

Dürrigl, Marija-Ana. (prir.). 2013. Hrvatska srednjovjekovna proza II: Apokrifi, vizije, prenja, Marijini mirakuli, Matica hrvatska, Zagreb.

Dürrigl, Marija-Ana. 2007. Čti razumno i lipo. Ogledi o hrvatskoglagoljskoj srednjovjekovnoj književnosti, Hrvatska sveučilišna naklada, Zagreb.

Dürrigl, Marija-Ana. 2003. Osobitosti hrvatskoglagoljskoga teksta Milost' i Istina sretosta se Pravda i Mir' obcelivasta se, "Umjetnost riječi”, sv. 47, br. 3-4, str. 141-153.

Fališevac, Dunja. ${ }^{2}$ 1989. Stari pisci hrvatski i njihove poetike, Hrvatska sveučilišna naklada, Zagreb.

Glier, Ingeborg. 1984. Allegorien, u: Epische Stoffe des Mittelalters (ur. Volker Mertens i Ulrich Müller), Kröner Verlag, Stuttgart, str. 203-228.

Grmača, Dolores. 2015. Nevolje stijelom. Alegorija putovanja od Bunića do Barakovića, Matica hrvatska, Zagreb.

Hildegard von Bingen. 2014. Das Buch der Lebensverdienste - Liber vitae meritorum (prev. Maura Zátonyi), Abtei St. Hildegard Beuroner Kunstverlag, Rüdesheim/ Eibingen Beuron.

Hildegard von Bingen. 1998. Das Buch vom Wirken Gottes - Liber divinorum operum (prev. Mechthild Heieck), Pattloch Verlag, Augsburg.

Kartschoke, Dieter. 1984. Bibelepik, u: Epische Stoffe des Mittelalters (ur. Volker Mertens i Ulrich Müller), Kröner Verlag, Stuttgart, str. 20-39. 
Kienzle, Beverly. M. 2000. The Sermon (= Typologie des sources du Moyen Âge occidental 81-83), Brepols, Turnhout.

Maconi, David. V., Eleonore Stump (ur.). 2014. The Cambridge Companion to Augustine, Cambridge University Press, Cambridge.

Minnis, Alastair. J. 2000. Quadruplex Sensus, Multiplex Modus: Scriptural Sense and Mode in Medieval Scholastic Exegesis, u: Interpretation and Allegory. Antiquity to the Modern Period (ur. Jon Whitman), Brill, Leiden - Boston - Köln, str. 231-256.

Newman, Barbara. 2001. God and the Goddesses: Vision, Poetry, and Belief in the Middle Ages, u: Poetry and Philosophy in the Middle Ages. A Festschrift for Peter Dronke (ur. John Marenbon), Brill, Leiden - Boston - Köln, str. 173-196.

Owst, Gerald. R. 1933. Literature and Pulpit in Medieval England, University Press, Cambridge.

Prill, Paul. E. 1987. Rhetoric and Poetics in the Early Middle Ages, "Rhetorica" 5, str. 129-147.

Sambunjak, Slavomir. 2000. Jezik i stil hrvatskih glagoljskih prenja, Književni krug, Split.

Schulze, Alfred. 1980. Predigten des hl. Bernhard in altfranzösischer Übertragung, Georg Olm Verlag, Hildesheim New York.

Strohal, Rudolf. 1917. Stare hrvatske apokrifne priče i legende, Lavoslav Weiss, Bjelovar.

Vajs, Josef. 1916. Psalterium paleoslovenicum croatico-glagoliticum, Politika, Praha. Zátonyi, Maura. 2012. Vidi et intellexi Die Schrifthermeneutik in der Visionstrilogie Hildegards von Bingen, Aschendorff Verlag, Münster.

\section{IZVORI}

Akademijin zbornik različitoga duhovnoga štiva (konac 15. st.), Zagreb, Arhiv HAZU, sign. IV a 48.

Zbirka legendi popa Duma Grege (1773), Zagreb, NSK, sign. R 3375.

Lobkovicov psaltir (1359), Prag, Státní knihovna ČR, sign. XXIII G 67.

Pariški psaltir (15. st.), Pariz, Bibliothèque Nationale, sign. Slave 11.

Biblija. Stari i novi zavjet, Kršćanska sadašnjost, Zagreb 1987.

Biblia Sacra juxta Vulgatam Clementinam. Editio electronica. Plurimis consultis editionibus diligenter praeparata a Michaele Tvveedale, Londini MMV - preuzeto s www.wilbourhall.org/pdfs/vulgate.pdf

Septuaginta. Id est Vetus Testamentum graece iuxta LXX interpretes, edidit Alfred Rahlfs, Deutsche Bibelgesellschaft, Stuttgart 2006 - preuzeto s www.sbl-site.org/assets/pdfs/ bibletexts/Septuaginta/SEPTUAGINTA_SBL.pdf 


\section{SUMMARY \\ VARIETAS DELECTAT - A NEW APPROACH TO A CROATIAN GLAGOLITIC TEXT}

The title of the most intricate Croatian Glagolitic dispute is a direct quotation from the Bible: Milost' i Istina sretosta se Pravda i Mir' obcelivasta se (Psalm 85,11 or 84,11). This opens new paths for the understanding of this allegorical text and its multi-layered meaning. I propose the term estrangement for the focal structural technique applied, because the Biblical stories of Adam's fall, Christ's redemptive sacrifice and the looming Judgement Day are told through a series of new but easily recognizable motifs. The structure of the texts includes narration, debate and sermon, which indicates that it was primarily intended for the audience familiar with lectio divina. The work as a whole indicates that the author (and hence the translator) aimed to achieve the effect of variation: the constant return to the initial debate between the Four Daughters of God (i.e. the personified virtues of Charity, Truth, Justice and Peace), albeit always with some degree of variety in introducing new elements and stylistic procedures. This creates an effect of a musical rondo and is at the same time a form of ruminatio because it constantly keeps reminding the audience of the main plot. The work is distinctive because it comprises not only a debate between the characters, but also a multilayered exegesis of the narrated events. On the agar of a Psalm quotation allegory was born a debate between the Daughters of God, and a paraphrase of the Biblical history of salvation, as well as a multi-layered exegesis. Its complex composition makes this text unique among preserved Croatian Glagolitic debates/contrasts.

Keywords: Croatian Glagolitic literature, debates, composition, Bible, allegory 